\title{
Development of Lassi Using Whey and Moringa Powder
}

\author{
Neeraj Kumar Dixit ${ }^{1}$, S.K. Aktar Hossain ${ }^{1 *}$, Binod Kumar Bharti ${ }^{2}$, \\ Shankar Suwan Singh ${ }^{1}$ and Simar Mishra ${ }^{1}$ \\ ${ }^{1}$ Warner College of Dairy Technology, SHUATS, Allahabad (UP), India \\ ${ }^{2}$ SGIDT (Bihar Animal Sciences University) Patna (Bihar), India \\ *Corresponding author
}

\begin{tabular}{|l|}
\hline Ke y w o r d s \\
Curd, Sugar, Whey, \\
Moringa powder, \\
Vanilla flavor \\
\hline Article Info \\
\hline $\begin{array}{l}\text { Accepted: } \\
\text { 07 October } 2018 \\
\text { Available Online: } \\
10 \text { November } 2018\end{array}$ \\
\hline
\end{tabular}

\section{Introduction}

Milk contains numerous nutrients and it makes a significant contribution to meeting the body's needs for calcium, magnesium, riboflavin, selenium, thiamin and pantothenic acid. Tremendous changes in life style and eating habits have resulted in multiplication of health problems such as anorexia, cancer, diabetes and various neurodegenerative
In current time, people of all age groups required different types of vitamin, mineral, protein etc. which are sufficient available in moringa lassi. Lassi is one of the most popular options all over the global liked by people of all age groups. It is resolve health problem and also provides enough nutrition at a low cost to a large population. The present study was conducted to know the physico-chemical and microbial attribute of moringa lassi prepared by blending with dahi, whey and moringa powder. It was prepared from standardization milk. Moringa powder was added different level $(0.5 \%),(1 \%)$, and $(1.5 \%)$ of milk and whey syrup. Addition of whey at three different concentration $(19 \%, 29 \%$ and $39 \%$ ), pectin $(0.1 \%)$ and vanilla improved quality and acceptability of the product of moringa lassi. Various analysis parameters were analyzed by two way ANOVA to obtained optimum result prepared moringa lassi was subjected to chemical and microbial analysis to evaluate the suitability of lassi were sample carbohydrate $\mathrm{T}_{3}(16.69 \%)$, protein $\mathrm{T}_{3}(3.01 \%)$, fat $\mathrm{T}_{0}(2.47), \operatorname{ashT}_{3}(0.82)$, Total solid $\mathrm{T}_{3}(23.10)$, Lactic acidity $\mathrm{T}_{0}(0.87), \mathrm{pH}$ $\mathrm{T}_{0}$ (4.08) and Viscosity (cp) (252.12). The highest mean value of Yeast and Mould count was recorded in the Moringa lassi of $\mathrm{T}_{0}\left(7.80 \times 10^{1}\right)$ and SPC of Moringa lassi $\mathrm{T}_{0}$ $\left(19.00 \times 10^{7}\right)$. Based on the result it was indicated that beneficial component of high protein in curd, Whey and Moringa powder made them more favorable choice for dairy technologist to develop lassi especially for healthy food. 
fermented dairy products as compared to the milk from which they are made. The demand for fermented milk product is increasing and it has been estimated that about $10 \%$ of total milk produced in India is used for preparation of traditional fermented milk products (Khurana and Kanawjia, 2007).

Lassi is one of the major fermented milk products which is ideal for serving with dishes and it help the body to digest the spicy food. Lassi is a digestive aid for the afternoon meal, it settles the upset stomach and it is the perfect cooling agent (Anonymous, 2006). Lassi is a traditional beverage having its origin in India and popular in South Asia in different varieties. It is a "ready-to-serve" fermented milk beverage popular in our country especially in summer season. This popular indigenous fermented milk beverage, is usually prepared by mixing dahi and water in required proportions. Along with all the essential nutrients required for growth, development and tissue differentiation, fermented milk contain growth hormonesgastrin and insulin (Arora, 2006). A mixed mesophilic cultures of Lactococcus lactis subsp. lactis, Lactococcus lactis subsp. cremoris, Lactococcus lactis sub sp. diacetyl lactis along with Leuconostoc species are grown together for production of dahi. The major function of a starter culture is the production of lactic acid at a suitable rate to ensure a consistent and successful fermentation (OMcKay et al., 1990). Lassi contains appreciable amount of milk proteins and phospholipids and is an excellent beverage for quenching thirst because of its lactic acidity. Fermented special products are of interest in the development of new products for the several reasons. Due to the expanding market of dairy companies, there has been a merging of dairy product and fruit beverage markets, with the introduction of hybrid dairy products, such as Juice ceuticals, offering health, flavour and convenience (Khurana and
Kanawjia, 2007). Fruit lassi has very low shelf life and hence there is a need to develop process technology for ready to reconstitute shelf stable convenient fruit lassi powders with good retention of antioxidants and vitamins. Although some reports are available on spray dried lassi powders and convective air dried dahi and mango soy fortified yoghurt powder (Kumar and Mishra, 2004; Shiby and Mishra, 2008). The developed a lassi-type cultured beverage from cheese whey (Kumar et al., 1987). Lassi using buttermilk and soyabean was made (Deka et al., 1984).

Whey is major by-product of dairy industry, during manufacture of products like paneer, channa, cheese, chakka, casein etc. In the manufacturing of these products, about 10- 20 per cent portion of milk is recovered as the desired end product and remaining 80-90 per cent liquid portion is the whey. The development of whey based beverages using paneer whey, cheese whey and various fruit juices (mango, pineapple, lemon and banana) at levels ranging from 73 to 87 percent and 5 to 20 percent respectively (Singh et al., 1994).The technology for the manufacture of guava-whey beverage was standardized (Singh et al., 1999). Studies revels that whey contains $45-50 \%$ of total milk solids, $70 \%$ of milk sugars, $20 \%$ of milk proteins, $70-90 \%$ of milk minerals and almost all water soluble vitamins present in milk. By realizing the functional properties of whey, many industries targets upon utilizing whey as the functional food ingredient. Direct utilization of whey in the form of beverage is one of the most attractive avenues for utilizing whey for human consumption (Goyaland Gandhi, 2009). The growing obesity epidemic is a worldwide concern. Obesity contributes to health issues that result from carrying increased fat mass such as sleep apnea, osteoarthritis and joint and skin abnormalities and health issues that result from the metabolic effect of fat cells such as type 2 diabetes, insulin resistance, 
metabolic syndrome, hypertension, nonalcoholic fatty liver disease, heart disease, gallbladder disease and cancer (Park et al., 2005).

'Moringa oleifera' is commonly known as Drumstick tree and it is a part of the family called Moringaceae. The use of Moringa oleifera parts including roots, leaves, flowers, green pods, seeds, steams and petioles, have various medicinal, nutrient, bioactive, antioxidant, and antimicrobial properties (Gopalakrishnan et al., 2016). Moringa has various nutritional properties, the leaves are loaded with medicinal benefits as they possess flavonol and phenolic acid which have the ability to inhibit prostate cancer and breast cancer. Root, bark, flower and leaf are used for treatment of infectious diseases along with cardiovascular and gastrointestinal disorders. The leaves also perform various pharmacological activities in our system, such as analgesic, antihypertensive, antitumor activity, and anti-inflammatory effects. The calorie content in $M$. oleifera leaves is also less, making it suitable for obese patients. It has been found that the leaves contain natural antioxidants such as vitamin $\mathrm{C}$, tocopherols, flavonoids and other phenolic compounds (Charoensin, 2014). Medical advantages of medicinal herbs have attracted food researchers to use it in designing novel functional dairy products and evaluate their impact on product quality and consumer acceptability (Yeyinka and Oyeyinka, 2016; Al-Turki et al., 2008). The minerals contents in $M$. oleifera and their bioavailability have been a subject of tremendous studies. There are however limited reports on the influence of variation in geographical locations or agroecology of $M$. oleiferaon the mineral composition in various organs of the plant in Nigeria. Moringa is rich in nutrition owing to the presence of a variety of essential phytochemicals present in its leaves, pods and seeds. In fact, Moringa is said to provide 7 times more vitamin $\mathrm{C}$ than oranges, 10 times more vitamin A than carrots, 17 times more calcium than milk, 9 times more protein than yoghurt, 15 times more potassium than bananas and 25 times more iron than spinach (Rockwood et al., 2013). The fact that moringa is easily cultivable makes it a sustainable remedy for malnutrition.

\section{Materials and Methods}

The experiment "Development of Lassi using by Whey and Moringa Powder" was carried out in the research lab of "CytoGene Research \& Development" B - Block Chauraha, Indra Nagar, Lucknow, India - 226016.

\section{Procurement and collection of ingredients}

Milk, moringa leaf powder, sugar and sugar were collected from the local market of Lucknow. Pectin, Citric acid was collected from the CytoGene Research and development, Lucknow.

\section{Treatment combination (Ratio)}

$\mathrm{T}_{0}$ - Control prepared from Dahi (100:00:00).

$\mathrm{T}_{1}$ - Experimental sample prepared from Dahi, Whey and Moringa powder (80:19.5:0.5).

$\mathrm{T}_{2}$ - Experimental sample prepared from Dahi, Whey and Moringa powder (70:29:1).

$\mathrm{T}_{3}$ - Experimental sample prepared from Dahi, Whey and Moringa powder (60:39.5:1.5).

\section{Plan of Work}

One litre of milk was standardized to $4.5 \%$ fat and $8.5 \%$ solid not fat and was converted to lassi as follows. The standardized milk was heated to $90^{\circ} \mathrm{C}$ for 15 minute, it was then cooled to $40^{\circ} \mathrm{C}$. This milk then inoculated by lactic starter culture @ of $1 \%$ and then milk is 
incubated, at $40^{\circ} \mathrm{C}$ until a firm coagulum (Dahi) was formed. The Dahi, so formed was broken and transfer 'to melt' Sugar @ 16\%, Moringa leaf powder was mix melt, to obtain the final product lassi (Fig. 1 and 2).

\section{Physico-chemical analysis of preparation of moringa lassi}

Determination of Titratable acidity- Samples (expressed as lactic acid) was determined as described in IS: 1479, Part I (1960). Determination of $\mathrm{pH}$ by digital $\mathrm{pH}$ meter as per AOAC (2005). Total solids- Total solids gravimetric method as described in IS: SP: 18, Part XI (1981).Fat - The fat percent was determined by Gerber method as described in IS: SP: 18, Part XI (1981).Viscosity - The viscosity of lassi samples was determined by using Brook field viscometer (J.C. (1866). Protein- The protein was determined by Kjhaldal methodas per AOAC (1995). Determination of Carbohydrate- Carbohydrate was estimated by Lane-Eynon's method described in IS: 1479, Part II (1961).Ash- Ash was estimated by muffle furnace as described in Ranganna (1986).

\section{Microbial analysis}

Yeast and mould count, coliform count and total count (was determined as per manual of Dairy Bacteriology ICAR 1972)

\section{Statistical analysis}

Data was analysed using Analysis of Variance (ANOVA) and Critical difference (C.D) in WASP software and excel software.

\section{Results and Discussion}

Data collected on the different aspects were tabulated and analyzed statistically using the method of analysis of variance and critical difference technique. The significant and non- significant differences observed have been analyzed critically within and between the treatment combinations. The present study was undertaken for development of Lassi using by Whey and Moringa Powder. The results obtained from the analyzed data are presented under physico-chemical parameters, microbiological characteristics and Statistical analysis.

\section{Physico-chemical characteristics}

\section{Carbohydrate content}

The mean value for carbohydrate percentage in control and experimental moringa lassi of different treatments are presented in table 1. It was statistically analyzed that mean value for carbohydrate of moringa lassi of $\mathrm{T}_{0}, \mathrm{~T}_{1}, \mathrm{~T}_{2}$, and $\mathrm{T}_{3}$ was found to be $16.21,16.48,16.69$ and 16.84 respectively. The moringa lassi prepared by blending with dahi, whey and moringa powder, carbohydrate percentage in samples of different treatments and control, the highest mean carbohydrate percentage was recorded in the sample of $\mathrm{T}_{3}$ (16.84) followed by $\mathrm{T}_{2}$ (16.69), $\mathrm{T}_{1}$ (16.48) and $\mathrm{T}_{0}$ (16.21). Kumar et al., (1987) observed slightly higher carbohydrates prepared a lassi type cultured beverage from a mixture of cheese whey and skim milk (95:5) by inoculating LF 40 culture. This indicates that, increased in proportion of whey and moringa powder in the blend increased the carbohydrates percentage of moringa lassi with significant differences $(\mathrm{P}<$ $0.05)$.

\section{Protein content}

That mean value for protein of moringa lassi of $\mathrm{T}_{0}, \mathrm{~T}_{1}, \mathrm{~T}_{2}$, and $\mathrm{T}_{3}$ was found to $2.70,2.76$, 2.89 and 3.01 respectively. The moringa lassi prepared by blending with dahi, whey and moringa powder, protein percentage in samples of different treatments and control, the highest mean protein percentage was 
recorded in the sample of $\mathrm{T}_{3}(3.01)$ followed by $\mathrm{T}_{2}(2.89), \mathrm{T}_{1}(2.76)$ and $\mathrm{T}_{0}(2.70)$. These results agree with the report of Kumar et al., (1987). Manish (2010) observed that $3.80 \%$ of protein prepared by preparation and quality evolution of Mango Lassi. Moringa lassi indicates that increased in proportion of whey and moringa powder in the blend increased the protein percentage of moringa lassi with significant differences $(\mathrm{P}<0.05)$. The result of ANOVA reveals that the $\mathrm{F}(\mathrm{Cal})$ value (89.66) was greater than the table value of $\mathrm{F}$ Tab (3.49) at 5\% level of significance. Therefore; the difference was significant, indicating significant effect of treatments on protein percent of moringa lassi.

\section{Fat content}

The mean value for fat percentage of moringa lassi of $\mathrm{T}_{0}, \mathrm{~T}_{1}, \mathrm{~T}_{2}$, and $\mathrm{T}_{3}$ was found to 2.47, $2.42, \quad 2.39$ and 2.43 respectively. Fat percentage in samples of different treatments and control, the highest mean fat percentage of moringa lassi was recorded in the sample of $\mathrm{T}_{0}$ (2.47) followed by $\mathrm{T}_{3}(2.43), \mathrm{T}_{1}(2.42)$ and $\mathrm{T}_{2}$ (2.39). These results agreed with the report of Pardhi et al., (2014) for studies on finger millet lassi. Moringa lassi indicates that increased in proportion of whey and moringa powder in the blend decreased the protein percentage of moringa lassi with significant differences $(\mathrm{P}<0.05)$. The significant difference was further analyzed statistically to find out the C.D. between and within the different treatment combinations. The difference between the mean values of $\mathrm{T}_{0}-\mathrm{T}_{1}$ (0.04), $\mathrm{T}_{0}-\mathrm{T}_{2}(0.08)$ and $\mathrm{T}_{2}-\mathrm{T}_{3}(0.44)$ was equal than the C.D. value, 0.04. Therefore, the difference was significant.

\section{Ash content}

The mean value for ash percentage of moringa lassi of $\mathrm{T}_{0}, \mathrm{~T}_{1}, \mathrm{~T}_{2}$, and $\mathrm{T}_{3}$ was found to 0.70 , $0.73,0.76$ and 0.82 respectively. The moringa lassi prepared by blending with dahi, whey and moringa powder, ash percentage in samples of different treatments and control, the highest mean ash percentage was recorded in the sample of $T_{3}(0.82)$ followed by $T_{2}$ (0.76), $\mathrm{T}_{1}(0.73)$ and $\mathrm{T}_{0}(0.70)$. Moringa lassi indicates that increased in proportion of whey and moringa powder in the blend increased the ash percentage of moringa lassi. The result of ANOVA given, the F (Cal) value (13.20) was greater than the table value of F Tab. (3.49) at $5 \%$ level of significance. Therefore; the difference was significant, indicating significant effect of treatments on ash percent.

\section{Total solid content}

The mean value for total solid percentage in control and experimental moringa lassi of different treatments are presented in table 1. It was statistically analyzed that mean value for total solid of moringa lassi of $\mathrm{T}_{0}, \mathrm{~T}_{1}, \mathrm{~T}_{2}$, and $\mathrm{T}_{3}$ was found to $22.09,22.40,22.74$ and 23.10 respectively. The moringa lassi prepared by blending with dahi, whey and moringa powder, Total solid percentage in samples of different treatments and control, the highest mean percentage was recorded in the sample of $\mathrm{T}_{3}$ (23.1) followed by $\mathrm{T}_{2}$ (22.74), $\mathrm{T}_{1}$ (22.39) and $\mathrm{T}_{0}$ (22.08). Kumar et al., (1987) observed slightly lower TS prepared a lassi type cultured beverage from a mixture of cheese whey and skim milk (95:5) by inoculating LF 40 culture. Moringa lassi indicates that increased in proportion of whey and moringa powder in the blend increased the total solid percentage of moringa lassi with significant differences $(\mathrm{P}<0.05)$. The significant difference was further analyzed statistically to find out the C.D between and within the different treatment combinations. The difference between the mean values of $\mathrm{T}_{0}-\mathrm{T}_{1}$ (0.31), $\mathrm{T}_{0}-\mathrm{T}_{2}(0.65), \mathrm{T}_{0}-\mathrm{T}_{3}(1.01), \mathrm{T}_{1}-\mathrm{T}_{2}(0.34)$, $\mathrm{T}_{1}-\mathrm{T}_{3}(0.70)$ and $\mathrm{T}_{2}-\mathrm{T}_{3}(0.36)$ was greater than the C.D. value, 0.06 Therefore, the difference was significant. 
Table.1 Average data for different parameters of control and experiments of Development of Lassi using by Whey and Moringa Powder

\begin{tabular}{|c|c|c|c|c|}
\hline \multirow[t]{2}{*}{ Parameters } & \multicolumn{4}{|c|}{ Treatment } \\
\hline & $\mathrm{T}_{0}$ & $\mathrm{~T}_{1}$ & $\mathrm{~T}_{2}$ & $\mathrm{~T}_{3}$ \\
\hline \multicolumn{5}{|c|}{ Physico-chemical analysis } \\
\hline Carbohydrate \% & $16.21 \pm 0.03$ & $16.48 \pm 0.05$ & $16.69 \pm 0.03$ & $16.84 \pm 0.05$ \\
\hline Protein \% & $2.70 \pm 0.02$ & $2.76 \pm 0.04$ & $2.89 \pm 0.10$ & $3.01 \pm 0.04$ \\
\hline Fat $\%$ & $2.47 \pm 0.03$ & $2.42 \pm 0.02$ & $2.39 \pm 0.02$ & $2.43 \pm 0.03$ \\
\hline $\operatorname{Ash} \%$ & $0.70 \pm 0.02$ & $0.73 \pm 0.02$ & $0.77 \pm 0.02$ & $0.82 \pm 0.05$ \\
\hline Total Solids\% & $22.08 \pm 0.04$ & $22.39 \pm 0.08$ & $22.74 \pm 0.03$ & $23.10 \pm 0.03$ \\
\hline Acidity \% (lactic acid) & $0.87 \pm 0.01$ & $0.84 \pm 0.02$ & $0.82 \pm 0.02$ & $0.80 \pm 0.04$ \\
\hline pH & $4.08 \pm 0.02$ & $4.05 \pm 0.04$ & $4.07 \pm 0.04$ & $4.03 \pm 0.04$ \\
\hline Viscosity (cp) & $243.23 \pm 0.02$ & $247.00 \pm 0.56$ & $252.12 \pm 0.04$ & $258.18 \pm 0.03$ \\
\hline \multicolumn{5}{|c|}{ 2.Microbial analysis } \\
\hline Yeast \&mold $\left(\times 10^{1} \mathrm{cfu} / \mathrm{ml}\right)$ & $7.8 \pm 1.30$ & $5.8 \pm 0.83$ & $5.4 \pm 1.14$ & $6.6 \pm 1.51$ \\
\hline $\mathrm{SPC}\left(\times 10^{7} \mathrm{cfu} / \mathrm{ml}\right)$ & $19 \pm 2.12$ & $16.6 \pm 2.07$ & $15.8 \pm 2.16$ & $17.6 \pm 1.67$ \\
\hline Coliform count & NIL & NIL & NIL & NIL \\
\hline
\end{tabular}

Fig.1 Flow Diagram for preparation of Whey

Milk<smiles>C1CCCCC1</smiles>

Standardized to $4.5 \%$ fat \& $8.5 \%$ SNF heated

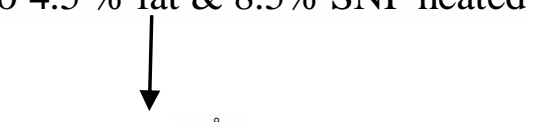

Cool to $78^{\circ} \mathrm{C}$

Coagulate milk with $2 \%$ Citric acid

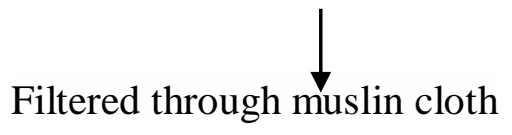

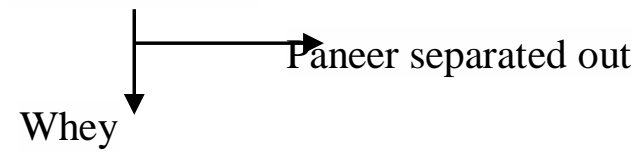


Fig.2 Flow Diagram for Preparation of Moringa Lassi

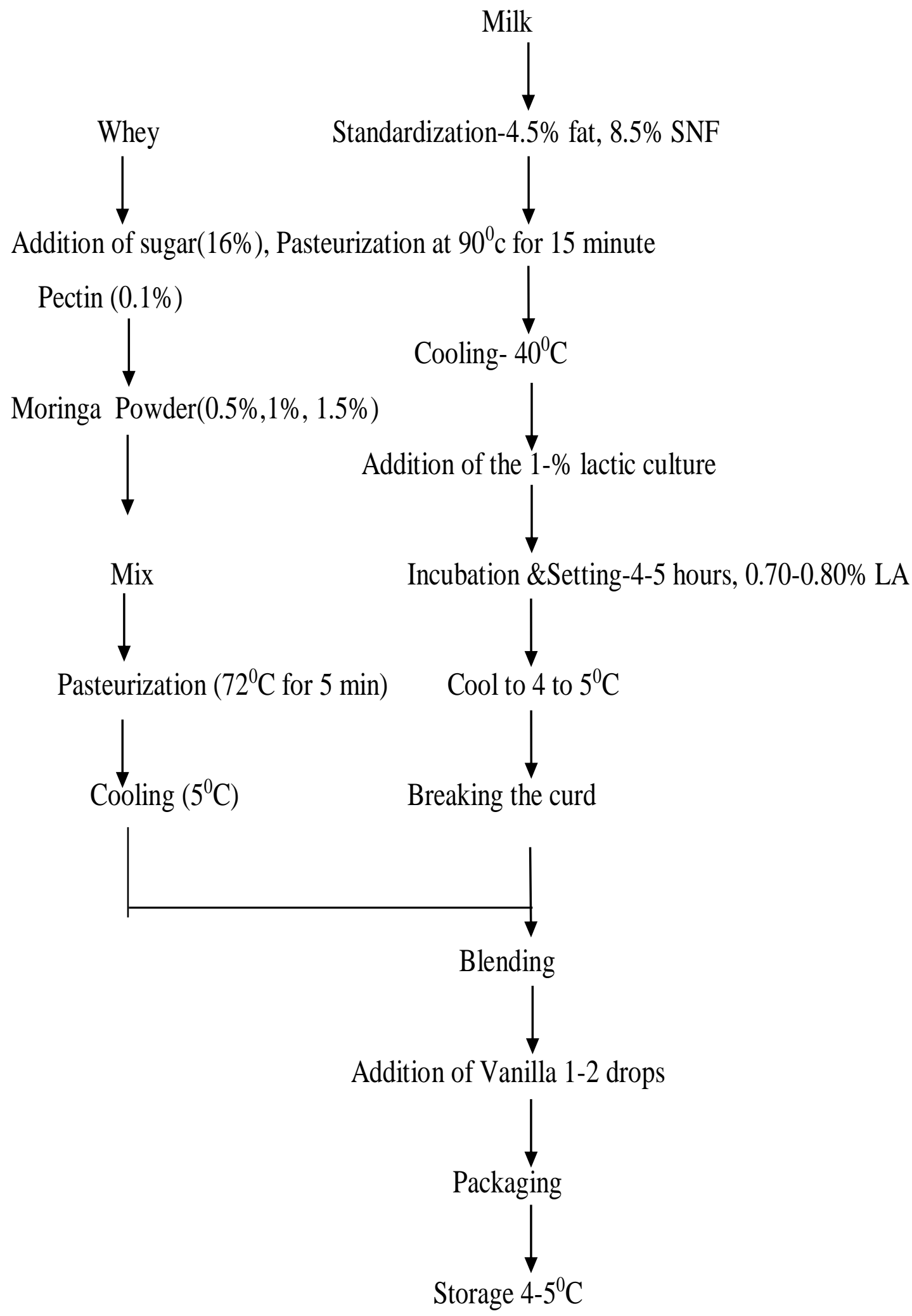


Fig.3 average physico-chemical analysis of control and experimental samples of Moringa lassi

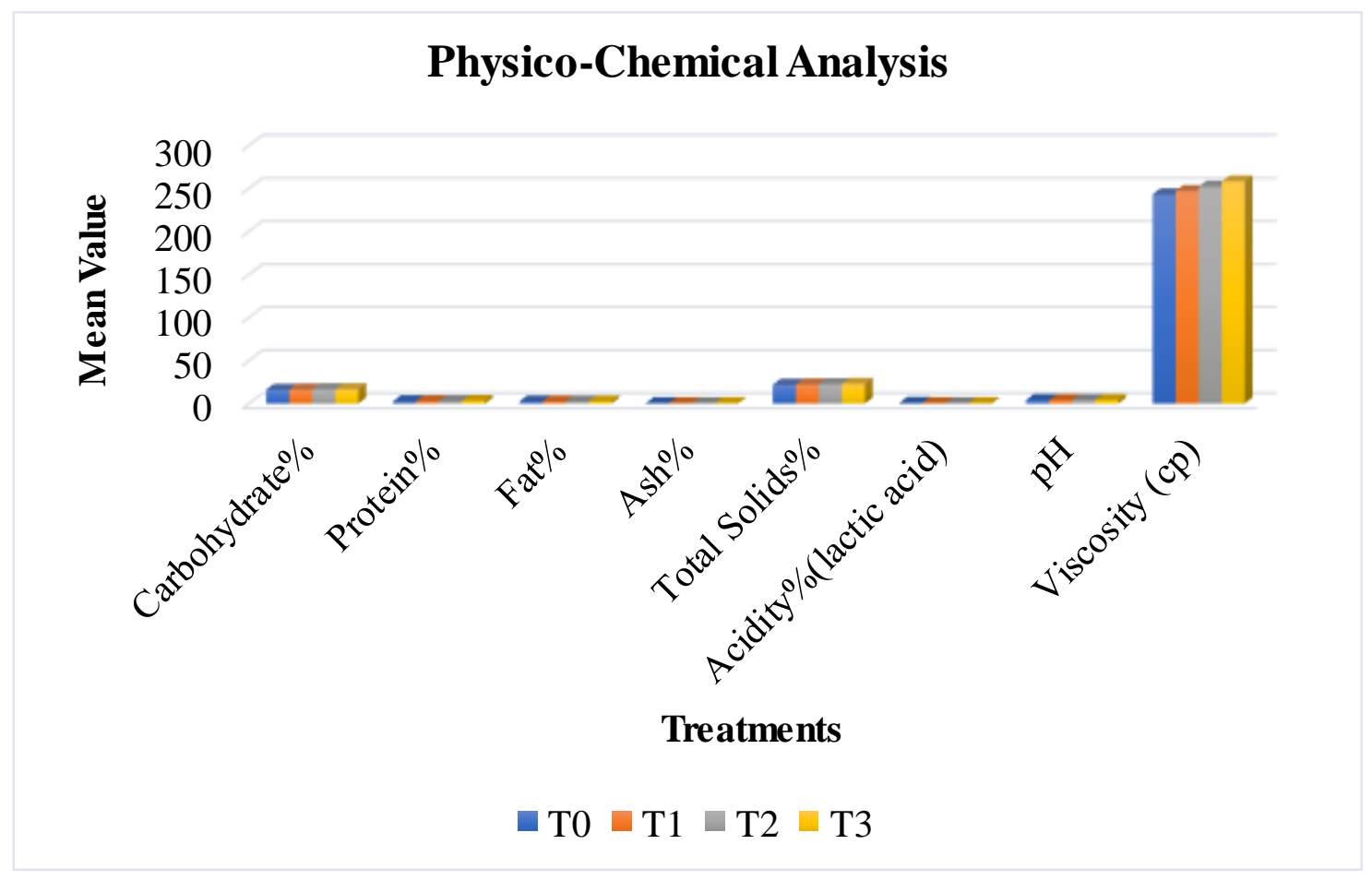

Fig.4 Average yeast and mould and SPC count of control and experimental samples of Moringa lassi

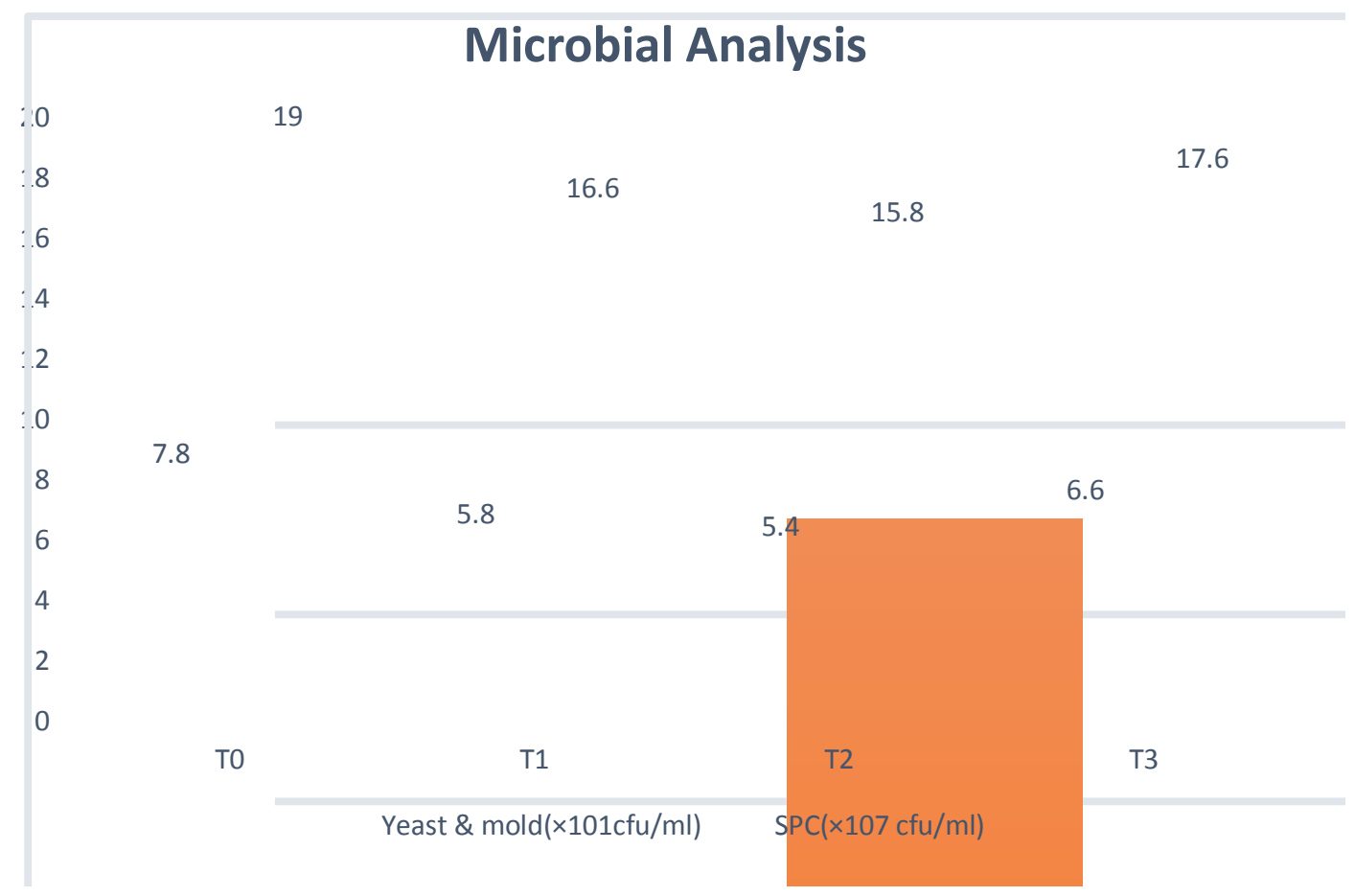




\section{Acidity content}

The mean value for acidity of moringa lassi of $\mathrm{T}_{0}, \mathrm{~T}_{1}, \mathrm{~T}_{2}$, and $\mathrm{T}_{3}$ was found to $0.88,0.84$, 0.83 and 0.80 respectively. The moringa lassi prepared by blending with dahi, whey and moringa powder, Acidity percentage in samples of different treatments and control, the highest mean Acidity percentage was recorded in the sample of $\mathrm{T}_{0}(0.88)$ followed by $\mathrm{T}_{1}(0.84), \mathrm{T}_{2}(0.82)$ and $\mathrm{T}_{3}(0.80)$. Pardhi et al., (2014) observed slightly lower acidity prepared for finger millet lassi. Moringa lassi indicates that increased in proportion of whey and moringa powder in the blend decreased the acidity percentage of moringa lassi with significant differences $(\mathrm{P}<0.05)$.Acidity level was slightly lower in sample $T_{1}$ to $T_{3}$ than control $T_{1}$ because of the effect of whey and moringa on lactic acid bacteria. The significant difference was further analyzed statistically to find out the C.D. between and within the different treatment combinations. The difference between the mean values of $\mathrm{T}_{0}-\mathrm{T}_{2}$ (0.05), $\mathrm{T}_{0}-\mathrm{T}_{3}$ (0.07) and $\mathrm{T}_{1}-\mathrm{T}_{3}(0.04)$ was greater than the C.D. value, 0.04 Therefore, the difference was significant. The difference between the mean values of $\mathrm{T}_{0}-\mathrm{T}_{1}$ (0.03), $\quad \mathrm{T}_{2}-\mathrm{T}_{3}$ (0.02) and $\mathrm{T}_{2}-\mathrm{T}_{3}$ (0.02) was lower than the C.D. value, 0.04 Therefore, the difference was non-significant of moringa lassi.

\section{pH}

$\mathrm{pH}$ of moringa lassi was inversely proportional to the acidity levels. The mean value for $\mathrm{pH}$ of moringa lassi of $\mathrm{T}_{0}, \mathrm{~T}_{1}, \mathrm{~T}_{2}$, and $\mathrm{T}_{3}$ was found to 4.08, 4.05, 4.08 and 4.04 respectively. The moringa lassi prepared by blending with dahi, whey and moringa powder, $\mathrm{pH}$ in samples of different treatments and control, the highest mean $\mathrm{pH}$ was recorded in the sample of $\mathrm{T}_{0}$ (4.08) followed by $\mathrm{T}_{2}$ (4.08), $\mathrm{T}_{1}$ (4.05) and $\mathrm{T}_{3}$ (4.03) with significant differences $(\mathrm{P}<0.05)$. These results also agree with the results of Bagal et al., (2007).The significant differencewas obtained analyzed statistically to find out the C.D. between and within the different treatment combinations. The difference between the mean values of $\mathrm{T}_{0}-\mathrm{T}_{3}(0.04)$ was greater than the C.D. value, 0.04 Therefore, the difference was significant and the difference between the mean values of $\mathrm{T}_{0}-\mathrm{T}_{1}$ (0.03), $\mathrm{T}_{0}-\mathrm{T}_{2}$ (0.006), $\mathrm{T}_{1}-\mathrm{T}_{2}$ (0.02), $\mathrm{T}_{1}-\mathrm{T}_{3}$ (0.01) and $\mathrm{T}_{2}-\mathrm{T}_{3}(0.03)$ was lower than the C.D. value, 0.04 Therefore, the difference was non-significant of moringa lassi.

\section{Viscosity}

The mean value for viscosity (centi poise) of moringa lassi of $\mathrm{T}_{0}, \mathrm{~T}_{1}, \mathrm{~T}_{2}$, and $\mathrm{T}_{3}$ was found to $243.22,247.27,252.07$ and 258.14 respectively. The moringa lassi prepared by blending with dahi, whey and moringa powder, viscosity in samples of different treatments and control, the highest mean viscosity (centi poise) was recorded in the sample of $\mathrm{T}_{3}$ (258.14) followed by $\mathrm{T}_{2}$ (252.07), $\mathrm{T}_{1}$ (247.27) and $\mathrm{T}_{0}$ (243.22). It indicates that increased in proportion of whey and moringa powder in the blend decreased the viscosity content of moringa lassi. The significant difference was analyzed statistically to find out the C.D. between and within the different treatment combinations. The difference between the mean values of $\mathrm{T}_{0}-\mathrm{T}_{1}$ (4.05), $\mathrm{T}_{0}-\mathrm{T}_{2}$ (8.85), $\mathrm{T}_{0}-\mathrm{T}_{3}$ (14.92), $\mathrm{T}_{1^{-}}$ $\mathrm{T}_{2}$ (4.80), $\mathrm{T}_{1}-\mathrm{T}_{3}(10.87)$ and $\mathrm{T}_{2}-\mathrm{T}_{3}(6.06)$ was greater than the C.D. value, 0.38 Therefore, the difference was significant (Fig. 3).

\section{Yeast and mould count}

The mean value for yeast and mould counts $\left(\times 10^{1}\right)$ of moringa lassi of $\mathrm{T}_{0}, \mathrm{~T}_{1}, \mathrm{~T}_{2}$, and $\mathrm{T}_{3}$ was found to $7.80,5.80,5.40$ and 6.60 respectively. The moringa lassi prepared by blending with dahi, whey and moringa powder, Yeast and count samples of different 
treatments and control, the highest mean Yeast and mold count was recorded in the sample of $\mathrm{T}_{0}$ (7.80) followed by $\mathrm{T}_{3}$ (6.60), $\mathrm{T}_{1}$ (5.80) and $\mathrm{T}_{2}$ (5.40). Moringa lassi indicates that increased in proportion of whey and moringa powder in the blend decreased the yeast and mould count of moringa lassi. The significant difference was further analyzed statistically to find out the C.D. between and within the different treatment combinations. The difference between the mean values of $\mathrm{T}_{0}-\mathrm{T}_{1}(2.00)$ was greater than the C.D. value, 1.33 Therefore, the difference was significant. The difference between the mean values of $\mathrm{T}_{0}-\mathrm{T}_{3}$ (1.2), $\mathrm{T}_{1}-\mathrm{T}_{2}(0.4), \mathrm{T}_{1}-\mathrm{T}_{3}(0.8)$ and $\mathrm{T}_{2}-\mathrm{T}_{3}$ (1.2) was lower than the C.D. value, 1.33 Therefore, the difference was no significant.

\section{SPC count}

The mean value for SPC $\left(\times 10^{7}\right)$ of moringa lassi of $\mathrm{T}_{0}, \mathrm{~T}_{1}, \mathrm{~T}_{2}$, and $\mathrm{T}_{3}$ was found to $19.00,16.60$, 15.80 and 17.60 respectively. The moringa lassi prepared by blending with dahi, whey and moringa powder, SPC (cfu/gm) in samples of different treatments and control, the highest mean SPC (cfu/gm) was recorded in the sample of $\mathrm{T}_{0}$ (19.00) followed by $\mathrm{T}_{3}$ (17.6), $\mathrm{T}_{1}$ (16.6) and $\mathrm{T}_{2}$ (15.8) (Fig. 4).

\section{Coliform count}

The mean value for SPC of moringa lassi of $\mathrm{T}_{0}$, $\mathrm{T}_{1}, \mathrm{~T}_{2}$, and $\mathrm{T}_{3}$ was found to be absent. From the study conducted, it can be concluded that a health beverage like Lassi can be prepared by incorporating whey and moringa powder for better functionality. The highest mean of carbohydrate percentage was recorded in the Moringa lassi sample of $\mathrm{T}_{3}$ (16.84), followed by $\mathrm{T}_{2}$ (16.69), $\mathrm{T}_{1}$ (16.48) and $\mathrm{T}_{0}$ (16.21). The highest mean of protein percentage was recorded in the Moringa lassi sample of $\mathrm{T}_{3}$ (3.01) and lowest was $T_{0}$ (2.70). Similarly, the highest mean of fat percentage was recorded in the Moringalassi sample of $\mathrm{T}_{0}$ (2.47) and lowest was $\mathrm{T}_{2}$ (2.39). Similarly, the highest mean of ash percentage was recorded in the Moringalassi sample of $\mathrm{T}_{3}(0.82)$ followed by $\mathrm{T}_{2}$
(0.77), $\mathrm{T}_{1}(0.73)$ and $\mathrm{T}_{0}(0.70)$. The highest mean of total solids percentage was recorded in the Moringa lassi sample of $\mathrm{T}_{3}$ (23.10) and lowest was $\mathrm{T}_{0}$ (22.08). The highest mean of Lactic acid percentage was recorded in the Moringa lassi sample of $\mathrm{T}_{0}(0.87)$ and lowest was $\mathrm{T}_{3}(0.80)$. The highest mean of $\mathrm{pH}$ was recorded in the Moringa lassi sample of $\mathrm{T}_{0}$ (4.08) and lowest was $T_{3}$ (4.03). Similarly, the highest mean of viscosity was recorded in the Moringa lassi sample of $\mathrm{T}_{3}$ (258.18) and lowest was $\mathrm{T}_{3}$ (243.23). The highest mean of Yeast and Mould recorded in the Moringa lassi sample of $\mathrm{T}_{0}$ (7.80) and lowest was $\mathrm{T}_{2}$ (5.40). The highest mean of SPC recorded in the Moringa lassi sample of $\mathrm{T}_{0}$ (19.00) and lowest was $\mathrm{T}_{2}$ (15.80). The coliform count in control and experimental sample were found to be absent. It may be concluded that, the Lassi of good quality and with more acceptability prepared having beneficial, value added and nutritionally enriched product. There was significant variation in respect of fat, protein, sucrose, total sugar and total solids content in all of the lassi samples examined.

\section{Acknowledgement}

Authors are grateful to Dean, Warner College of Dairy Technology, SHUATS, Allahabad for providing the necessary facilities to research work.

\section{References}

Al-Turki, A.I., El-Ziney, M.G. and AbdelSalam, A.M. 2008. Chemical and antibacterial characterization of aqueous extracts of oregano, marjoram, sage and licorice and their application in milk and labneh. J Food Agric Environ, 6: 39-44.

Anonymous 2006. Market profile on chilled drinks and snacks. http.//www.indian cookerylessons.com/fruit lassi.htm.

Arora, B. 2006. Health related properties of fermented milk products- A review. Indian J. Dairy Sci., 59(2): 57- 63. 
Bagal, S.G., Chavan, K.D., and Kulkarni, M.B. 2007. Studies on Preparation of Lassi From High Acid Cow Milk, J. Dairying, Foods \& H.S. 26 (2): 80-84, 2007

Charoensin, S. 2014. Antioxidant and anticancer activities of Moringa oleifera leaves. Journal of Medicinal Plants Research 8: 318-325.

Deka, D.D., Rajor, R.B. and Patil, G.R. 1984. Studies on the formulation of lassi (cultured milk) from soyabean and buttermilk. Egypt. J. Dairy Sci., 12: 291297.

Gopalakrishnan, L., Doriya, K. and Kumar, D. 2016. Moringa oleifera: A review on nutritive importance and its medicinal application, Food Science and Human Wellness, Vol. 5 (2): 49-56.

Goyal, N. and Gandhi, D. N. 2009. Comparative analysis of Indian paneer and cheese whey for electrolyte whey drink. World J. Dairy and Food Sci. 4: $70-72$

Khurana, H.K. and Kanawjia, S.K. 2007. Recent trends in development of fermented milks. Current Nutrition and Food Science, 3(1): 91-108.

Kumar, P. and Mishra, H.N. 2004. Storage stability of mango soy fortified yoghurt powder in two different packaging materials: HDPP and ALP. J Food Eng, 65(4): 569-576.

Kumar, R., Patil, G.R. and Rajor, R.B. 1987. Development of lassi-type cultured beverage from cheese whey. Asian Journal of Dairy Research, 6(3): 121-124.

Manish Kumar, 2010. Preparation and Quality Evalution of Mango Lassi, M.Sc. (Dairy Chemistry) Thesis, W.B.U.A. F.Sc. Kolkata (India)
OMcKay, L.L. and Baldwin, K.A. 1990. Applications for biotechnology: present and future improvements in lactic acid bacteria. FEMS Microbiol. rev., 87: 3-14.

Pardhi P.S., Desale R.J., Mule P.R., Ghule, B.K., Tambe D.R. and Gavhane, M.S. 2014. Studies on Finger Millet Lassi, Asian J. Dairy \& Food Res.., 33 (4): 255258, 2014

Park, H.S., Park, J.Y. and Yu, R. 2005. Relationship of obesity and visceral adiposity with serum concentrations of CRP, TNF-alpha and IL-6. Diabetes Res ClinPract. 69: 29-35.

Rockwood J.L., Anderson B.G., Casamatta D.A. 2013. Potential uses of Moringa oleifera and an examination of antibiotic efficacy conferred by $M$. oleifera seed and leaf extracts using crude extraction techniques available to underserved indigenous populations, Int. J. Phytothearpy Res. 3: 61-71.

Shiby, V.K. and Mishra, H.N. 2008. Modelling of acidification kinetics \& textural properties in buffalo milk curd (Indian yoghurt). Int J Dairy Technol, 61(3): 284289.

Singh, S., Ladkhani, B.G., Kumar, A. and Mathur, B.N. 1994. Development of whey based beverages. Indian J. Dairy Sci., 47(7): 586-590.

Singh, W., Kapoor, C.M. and Srivastava, D.N. 1999. Standardization of technology for the manufacture of guava-whey beverage. Indian J. Dairy Sci., 52(5): 268-271.

Yeyinka, A.T. and Oyeyinka, S.A. 2016. Moringa oleifera as a food fortificant: Recent trends and prospects. J Saudi SocAgricScience, 3: 1-10.

\section{How to cite this article:}

Neeraj Kumar Dixit, S.K. Aktar Hossain, Binod Kumar Bharti, Shankar Suwan Singh and Simar Mishra. 2018. Development of Lassi Using Whey and Moringa Powder. Int.J.Curr.Microbiol.App.Sci. 7(11): 602-612. doi: https://doi.org/10.20546/ijcmas.2018.711.073 